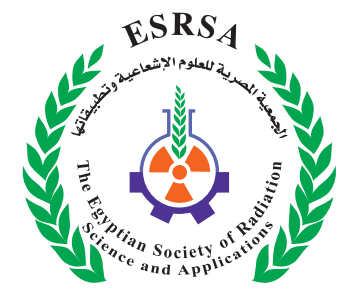

J. Nucl. Tech. Appl. Sci., Vol. 6, No. 2, PP. 93 : 105 (2018)

\title{
Isolation and Characterization of Phosphate Solubilizing Fungus in Vitro
}

\author{
El-Ghandour ${ }^{1}$, I.A.; Saadia M. Easa ${ }^{2}$; Abdel Aziz ${ }^{1}$, O.A.; Abeer M. Mousa ${ }^{1}$ and Heba G. Hussein ${ }^{1}$
}

Received: 03/05/2018

Accepted: 12/06/2018

E.mail:hebajaber661@gmail.com

\section{KEYWORDS}

Phosphate

Solubilization, Tri-

Calcium Phosphate,

$P$-Ase Enzyme,

P-Solubilizing Fungi

(PSF).

\section{ABSTRACT}

Series of laboratory (in vitro) examinations were carried out to recognize the most potent fungi isolates and optimum culture conditions helps in solubilizing sparing phosphate in soil. Therefore, the present study aimed to isolate and screening of phosphate solubilizing fungi (PSF), study the contribution of PSF on solubilization of tri-calcium phosphate through excretion of acid and alkaline phosphatase and determine the optimal conditions for phosphate solubilization. From 12 fungal isolates, only four were chosen depending on their capacity to convert tri-calcium - P into soluble one. In this regard, Aspergillus niger, Aspergillus flavus, Aspergillus ficuum and Fusarium oxysporum were efficient in producing halo zone around the colonies on petri dish. Aspergillus niger was the most efficient phosphate solubilizer on Pikovskaya's agar plates (PVK) achieving solubilization index (PSI) 2.4, followed by Aspergillus flavus with a $\mathrm{SI}=2.3$. The perfect activities of selected fungal isolates were detected with incubation periods 7 days and temperature $30^{\circ} \mathrm{C}$ for maximum phosphate solubilization, acid and alkaline phosphatase activities, $\mathrm{pH} 7.0$ for maximum phosphate solubilization, $\mathrm{pH} 6.0$ for maximum acid phosphatase activity while $\mathrm{pH} 8.0$ was suitable for maximum alkaline phosphatase activity for both A. niger and A.flavus.

1. Atomic Energy Authority, Nuclear Research Center, Soil and Water Research Department, Abou-Zaabal. Egypt.

2. Faculty of Science, Microbiology Department, Ain Shams University. 


\section{INTRODUCTION}

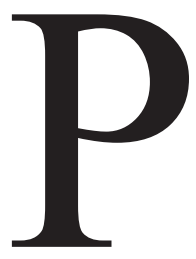

hosphorus (P) plays an essential biochemical role in photosynthesis, respiration, energy storage and transfer, cell division, cell vastness and some other processes in the living plant (Sagervanshi et al.,2012) . Egyptian soils have low available phosphorus that cannot meet the demands of plant (Reghab et al., 2010). Due to limited availability of chemical $-\mathrm{P}$ fertilizers under alkaline conditions (Podile and Kishore, 2006), the fungi could be used as safe, less expensive and ecofriendly agents that helps in converting insoluble $-\mathrm{P}$ into soluble one (Coutinho et al., 2012). Maize yield and $\mathrm{P}$ uptake were enhanced by Aspergillus inoculation (Xiao et al., 2013).

Organic P compounds undergo mineralization, and the resulting $\mathrm{P}$ is taken up as nutrient by plants. In this regard, numerous soil microbes or rhizosphere microflora possess the ability to transform organic P into soluble forms of P (Rodriguez et al., 2006). This mineralization process is mediated by the enzymes especially phosphatases (Aseri et al., 2009) and phytases (Maougal et al., 2014), released by the soil microbes. Richardson and Simpson (2011) pointed out that, A wide domain of fungi (e.g. Aspergillus and Penicillium spp. and bacteria (e.g. Actinomycetes, Pseudomonas, and Bacillus spp) produce the enzymes involved in organic P-mineralization. Phosphorus mineralization is an enzymatic process, involving phosphatases, which catalyze a variety of reactions capable of releasing phosphate from organic phosphorus compounds into the soil solution; phosphatases are released by microbes extracellular into the soil solution. Mineralization of organic phosphate affected by several factors such as temperature (the optimum being between $18^{\circ} \mathrm{C}$ to $40^{\circ} \mathrm{C}$ ), soil $\mathrm{pH}$ (the optimum occurring at soil $\mathrm{pH}$ 6.5), moisture, aeration, type of crop cultivated, the presence of growing plants, and the addition of fertilizer phosphate (Hyland et al., 2005). Microorgan- isms play a fundamental role in the biogeochemical cycling of phosphorus in natural ecosystems. As phosphate solubilization is a prime process for plant growth, the importance of phosphate solubilizing microorganisms is well recognized (Velazquezand Rodriguez-Barrueco, 2007). Inacbation periods, temperatures and $\mathrm{pH}$ are vital factors for various activities of microorganisms. Finally, correlations were developed between phosphate solubilization potential and associated factors, namely, incubation periods, temperatures and $\mathrm{pH}$.

The present study aimed to isolate and recognize the most potent fungi that have the highest activity under the examined optimum conditions (in vitro).

\section{MATERIALS AND METHODS}

\section{Collection of soil samples}

Soil samples were collected from different locations, i.e., Kulj (Great Cairo), Ras Sidr (South Saini Governorate), and Inshas (Sharkia Governorate). Soil sample was collected from the upper surface layer $(0-15 \mathrm{~cm})$. The soil samples were transferred to the laboratory in sterile polyethylene bags under aseptic conditions, and reserved in refrigerator at 5 ${ }^{\circ} \mathrm{C}$. Air dried soil was sieved through a 2-mm sieve.

\section{Isolation of fungal species}

Fungal strains were isolated from different soil samples on Dox's agar medium (Dox, 1910) (g/l): Sucrose, 20.0g; $\mathrm{NaNO}_{3}, 2.0 \mathrm{~g} ; \mathrm{KH}_{2} \mathrm{PO}_{4}, 1.0 \mathrm{~g}$; $\mathrm{MgSO}_{4} .7 \mathrm{H}_{2} \mathrm{O}, 0.5 \mathrm{~g} ; \mathrm{KCl}, 0.5 \mathrm{~g} ; \mathrm{FeSO}_{4} .5 \mathrm{H}_{2} \mathrm{O}, 0.001 \mathrm{~g}$; agar, $15.0 \mathrm{~g} .10 \mathrm{~g}$ of each soil sample was added to $90 \mathrm{ml}$ of $0.85 \% \mathrm{w} / \mathrm{v}$ of physiological saline. Ten fold dilution was made to drop $1 \mathrm{ml}$ of $\left(10^{-1}-10^{-7}\right)$ on plates containing Dox's agar medium. The plates were spread and incubated at $28^{\circ} \mathrm{C}$ for 7 days. After incubation period, growing fungal isolates were purified by repeated culturing and maintained on slants at $4{ }^{\circ} \mathrm{C}$ to be ready for identification. 


\section{Isolates identification}

Fungal isolates were Qualitatively identified by studying the cultural characters, i.e. colour, shape of colony, surface and reverse pigmentation, growth rate and texture of the colony as well as the microscopically structure (septate or non- septate hyphae, structure of hyphae and conidia) on Sabouraud's dextrose agar medium. Fungal isolates were identified according to Pitt (1979 and Pitt and Hocking (1985 and 1997) by Microbiology Department, Faculty of Science, Ain Shams University.

\section{Screening of P-solubilizing Fungal isolates}

\section{Qualitative method:}

Twelve fungal isolates were screened on selective Pikovskaysa's agar medium (PVK) (Pikovskaysa,1948) (g/l): $0.5 \mathrm{~g}\left(\mathrm{NH}_{4}\right)_{2} \mathrm{SO}_{4}, 0.5 \mathrm{~g} \mathrm{MgSO}_{4} \cdot 7 \mathrm{H}_{2} \mathrm{O}$, $0.3 \mathrm{~g} \mathrm{NaCl}, 0.3 \mathrm{~g} \mathrm{KCl}, 0.03 \mathrm{~g} \mathrm{FeSO}_{4} .7 \mathrm{H}_{2} \mathrm{O}, 0.02 \mathrm{~g}$ $\mathrm{MnSO}_{4} \cdot \mathrm{H}_{2} \mathrm{O}, 10.0 \mathrm{~g} \mathrm{Ca}_{3}\left(\mathrm{PO}_{4}\right)_{2}, 10.0 \mathrm{~g}$ Glucose and 15.0g Agar. Sterilized Pikovskaya's medium was poured into sterilized Petri dishes, after solidification on the dishes; a pinpoint inoculation of fungal strains was placed on the center of plates under aseptic conditions. The dishes were incubated at $28^{\circ} \mathrm{C}$ for 7 days. Solubilization index (SI) was calculated using the following equation (Edi - premono, 1996).

\section{Solubilizing index $=\frac{\text { Colony diameter+ Halo zone diameter }}{\text { Colony diameter }}$}

\section{Quantitative method:}

Fungal isolates with high ratio value of clear zone and maximum phosphate solubilization index (PSI) were used to solubilize tri-calcium phosphate (Quantitative method). Each flask was inoculated with $1 \mathrm{ml}$ of spore suspension $\left(1.0 \times 10^{6}\right.$ spores $\left./ \mathrm{ml}\right)$ of selected fungi. The flasks were incubated at 28 ${ }^{\circ} \mathrm{C}$ with rotary sheker at $200 \mathrm{rpm}$ for 7 days. The cultures were harvested by filtration with Whatman paper No. 42. The supernatants were analyzed for available phosphate according to Olsen et al. (1954) and alkaline and acid phosphatase activity was estimated as described by Tabatabai and Bremner (1969).
Optimization of culture conditions for phosphate solubilization

Sterilized PVK broth medium was exposed to different incubation periods, temperature and $\mathrm{pH}$. The un-inoculated autoclaved medium with phosphate substrate was incubated under similar conditions to serve as controls to all investigated parameters.

A set of triplicate culture flasks for each fungal isolate were established, each containing $50 \mathrm{~mL}$ of sterilized PVK broth medium at $\mathrm{pH}$ 7.0. Each flask was inoculated with $1 \mathrm{ml}$ of (10 ${ }^{6}$ spores $)$ of most potent fungal isolates (A.niger and A.flavus) for phosphatase enzymes production and incubated at $28^{\circ} \mathrm{C}$ at different incubation periods $(3,5,7,9,11$ and 14 days), respectively. Similar set of culture flasks were exposed to different temperatures of 20 , $25,30,35,40$ and $45^{\circ} \mathrm{C}$.

In addition, the PVK broth medium was individually adjusted at different values of $\mathrm{pH}$ by using $6 \mathrm{~N} \mathrm{HCL}$ or $6 \mathrm{~N} \mathrm{NaOH}$. The medium was inoculated with $1 \mathrm{ml}$ of $\left(10^{6}\right.$ spores) for both selected A.niger and A.flavus, and then were incubated at $30^{\circ} \mathrm{C}$ for 7 days.

Statistical Analysis: Experiments were carried out in triplicates. Statistical analysis was performed with Microsoft excel 2007. Difference on statistical analysis of data were considered Significant at $\mathrm{P}<0.05$. Comparisons between results were based on least significant difference (LSD) values derived from the analysis of variance. Tests with $\mathrm{p} \leq 0.05$ were considered statistically significant (Snedcor and Cochran, 1980).

\section{RESULTS}

\section{Isolation of fungal species}

Twelve fungal isolates were obtained as a result of the isolation and purification processes. Each fungal isolate was identified based on morophological features. 
These fungi are nine Aspergillus species, one Fusarium species, one Penicillium species and one Alternaria species.

\section{Screening of P-solubilizing fungi}

\section{Qualitative Method:}

Twelve fungal isolates of Aspergillus niger, A. flavus, A. japonicas, A. terricola, A. terreus, A. ficuum, A. flavipes, A. awamori, A. fumigatus, Fusarium oxysporum, Pencillium oxalicum and Alternaria alternata were assessed for phosphate solubilization Plate method on the basis of a clearance of zone on PVK medium at $28^{\circ} \mathrm{C}$ for 3 days was observed
From the 12 isolated fungi, only four showed a positive zone of $\mathrm{P}$ solubilization on PVK agar medium. Halo zone around fungal colonies was appeared (Fig. 1). The four isolates that displayed the highest ratio of clear zone / colony diameter were selected and considered as the more efficient $\mathrm{P}$ solubilizing fungi (PSF). The zone of $\mathrm{P}$ solubilization appeared on the third day of incubation. Continuous observation of the halo zone formation indicates phosphate solubilizing ability which was in increasing up to the 7 days of inoculation. Zone diameter was 7.2, 7.8, 6.3 and $3.8 \mathrm{~cm}$ for A. niger, A. flavus, A. ficuum and F. oxysporum, respectively (Table 2).

\section{(Table 1).}

Table (1) : Screening of fungi for tri-calcium phosphate solubilization [Positive means halo zone formation around the colony].

\begin{tabular}{|c|c|c|}
\hline Isolate No. & Name of isolated fungi & TCP Solubilization \\
\hline 1 & Aspergillus niger & Positive \\
2 & Aspergillus flavus & Positive \\
3 & Aspergillus japonicas & ND \\
4 & Aspergillus terricola & ND \\
5 & Aspergillus terreus & ND \\
6 & Aspergillus ficuum & Positive \\
7 & Aspergillus flavipes & ND \\
8 & Aspergillus awamori & ND \\
9 & Aspergillus fumigatus & ND \\
10 & Fusarium oxysporum & Positive \\
11 & Penicillium oxalicum & ND \\
12 & Alternaria alternate & ND \\
\hline
\end{tabular}

ND not detected

Table (2) : Estimation of solubilization index of tested fungal isolates.

\begin{tabular}{|c|c|c|c|}
\hline Fungal isolates & Colony diameter $(\mathbf{c m})$ & Halo zone diameter(cm) & $\begin{array}{c}\text { Solubilization index } \\
\text { (SI) }\end{array}$ \\
\hline Aspergillus niger & 5.1 & 7.2 & 2.4 \\
\hline Aspergillus flavus & 5.8 & 7.8 & 2.3 \\
\hline Aspergillus ficuum & 6.6 & 6.3 & 2.1 \\
\hline Fusarium oxysporum & 3.1 & 3.8 & 2.2 \\
\hline LSD $_{(0.05)}$ & $\mathbf{0 . 0 5}$ & $\mathbf{1 . 3 2}$ & \\
\hline
\end{tabular}

Calculated means is for triplicate measurements $\pm S D$ 


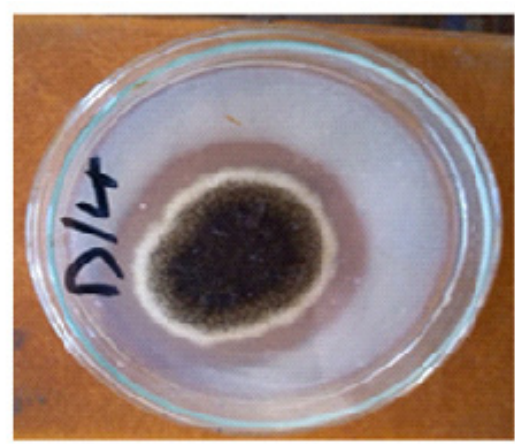

(A) Aspergillus niger

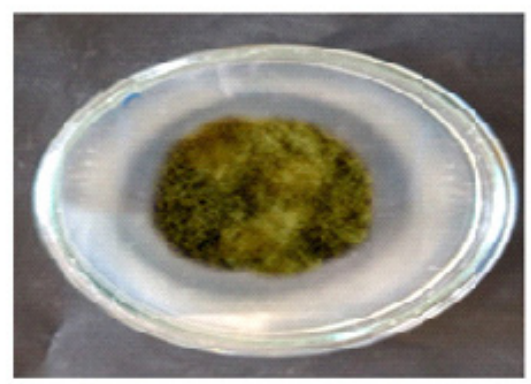

(C) Asperglilus flavus

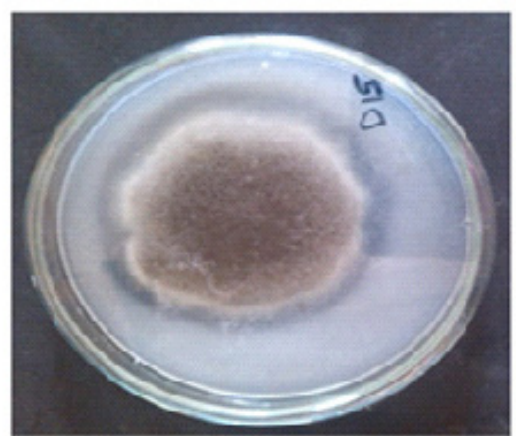

(B) Aspergillus ficuum

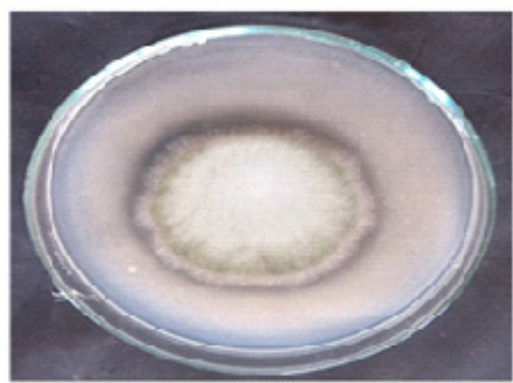

(D) Fusarium oxysporum

Fig. (1): Clearing zones around colonies of (A) Aspergillus niger, (B) Aspergillus ficuum, (C) Aspergillus flavus, (D) Fusarium oxysporum.

\section{Quantitative Assay}

Among four selected strains, A.niger was the most efficient solubilizer, where $\mathrm{SI}=2.4$, followed by A. flavus, A.ficuum and F. oxysporum (Table 2). According to its high SI, A.niger and A.flavus were selected for further examinations on qualitative and quantitative scales. A.niger achieved $73.8 \mu \mathrm{g} / \mathrm{ml}$ soluble -P followed by A. flavus $(72.6 \mu \mathrm{g} / \mathrm{ml})$. Acid phosphatase enzyme activity of $30.0 \mu \mathrm{g} / \mathrm{ml}, 23.5 \mu \mathrm{g} /$ $\mathrm{ml}, 17.5 \mu \mathrm{g} / \mathrm{ml}$ and $12.6 \mu \mathrm{g} / \mathrm{ml}$ were detected by $A$. niger, A. flavus, A. ficuum and F. oxysporum, respectively. While alkaline phosphatase enzyme activities were $45.7 \mu \mathrm{g} / \mathrm{ml}, 43.8 \mu \mathrm{g} / \mathrm{ml}, 34.7 \mu \mathrm{g} / \mathrm{ml}$ and 21.5 $\mu \mathrm{g} / \mathrm{ml}$ for the same sequence (Table 3).

Table (3) : Acid and alkaline phosphatase activities of fungal isolates.

\begin{tabular}{|c|c|c|c|}
\hline Fungal Isolates & $\begin{array}{c}\text { Soluble phosphate } \\
(\boldsymbol{\mu} \mathrm{g} / \mathrm{ml})\end{array}$ & $\begin{array}{c}\text { Acid phosphatase } \\
\text { Activity }(\boldsymbol{\mu g} / \mathbf{m l})\end{array}$ & $\begin{array}{c}\text { Alkaline } \mathbf{p h o s p h a t a s e} \\
\text { activity }(\boldsymbol{\mu g} / \mathbf{m l})\end{array}$ \\
\hline A. niger & 73.8 & 30.0 & 45.7 \\
\hline A. flavus & 72.6 & 23.5 & 43.8 \\
\hline A. ficuum & 73.5 & 17.5 & 34.7 \\
\hline F. oxysporum & 50.4 & 12.6 & 21.5 \\
\hline LSD $(\mathbf{0 . 0 5})$ & $\mathbf{3 . 2 5}$ & $\mathbf{1 . 5 4}$ & $\mathbf{1 . 5 1}$ \\
\hline
\end{tabular}

Calculated means is for triplicate measurements $\pm S D$ 
Effect of incubation periods on P solubilization .

Increasing phosphate solubilization was increased at fifth day of incubation period and reached to the maximum after 7 days (Table 4). The Maximum phosphate availability by $A$. niger and A. flavus
(56.53 and $43.23 \mu \mathrm{g} / \mathrm{ml}$ ), respectively were observed after 7 days followed by 9 days (54.16 and $42.26 \mu \mathrm{g}$ / $\mathrm{ml})$, respectively as compared to un-inoculated treatment. A decline occurred in PS from 9 days until the end of incubation period.

Table (4) : Effect of different incubation periods on phosphate solubilization $(\mu \mathrm{g} / \mathrm{ml})$ released by A. niger and A. flavus.

\begin{tabular}{|c|c|c|c|c|c|c|c|}
\hline \multicolumn{8}{|c|}{ Phosphate solubilization $(\mu \mathrm{g} / \mathrm{ml})$} \\
\hline \multirow{2}{*}{ Fungal sp. } & \multicolumn{6}{|c|}{ Incubation periods (days) } & \multirow{2}{*}{ Mean } \\
\hline & 3 & 5 & 7 & 9 & 11 & 14 & \\
\hline Un-inoculated & 8.45 & 8.60 & 10.10 & 9.57 & 9.46 & 10.18 & 9.39 \\
\hline A. niger & 33.20 & 41.13 & 56.53 & 54.16 & 52.46 & 50.53 & 48.00 \\
\hline A.flavus & 24.86 & 37.13 & 43.23 & 42.56 & 40.73 & 32.53 & 36.67 \\
\hline Mean & 22.17 & 28.95 & 36.62 & 35.43 & 34.22 & 31.08 & \\
\hline \multicolumn{8}{|c|}{ LSD 0.05: T: 0.39} \\
\hline
\end{tabular}

Calculated means is for triplicate measurements $\pm S D$

Notes: T: treatment ; F: fungi and TF : treatment * fungi

\section{Effect of incubation periods on phosphatase activity}

Maximum production of acid phosphatase enzyme by A. niger and A. flavus (46.70 and $41.20 \mu \mathrm{g} /$ $\mathrm{ml}$ ) were obtained after 7 days followed by 9 days (32.30 and $32.26 \mu \mathrm{g} / \mathrm{ml}$ respectively as compared to control $(0.95 \mu \mathrm{g} / \mathrm{ml}$ (Table 5). At the same time, the maximum alkaline phosphatase enzyme production by A. niger and A. flavus (67.13 and $53.13 \mu \mathrm{g} / \mathrm{ml}$ ), respectively were observed at 7 days followed by 9 days (45.86 and $43.70 \mu \mathrm{g} / \mathrm{ml}$ ) respectively.

Table (5) : Effect of different incubation periods on acid and alkaline phosphatase activities $(\mu \mathrm{g} / \mathrm{ml})$ induced by A. niger and A. flavus.

\begin{tabular}{|c|c|c|c|c|c|c|c|}
\hline \multicolumn{8}{|c|}{ Acid phosphatase activity $(\mu \mathrm{g} / \mathrm{ml})$} \\
\hline \multirow{2}{*}{ Fungal sp. } & \multicolumn{6}{|c|}{ Incubation periods (days) } & \multirow{2}{*}{ Mean } \\
\hline & 3 & 5 & 7 & 9 & 11 & 14 & \\
\hline Un-inoculated & 0.93 & 0.94 & 0.95 & 0.92 & 0.91 & 0.90 & 0.92 \\
\hline A. niger & 13.16 & 22.70 & 46.70 & 32.30 & 23.63 & 18.50 & 26.16 \\
\hline A.flavus & 12.60 & 32.26 & 41.20 & 32.26 & 21.66 & 18.06 & 26.34 \\
\hline Mean & 8.89 & 18.63 & 29.62 & 21.82 & 15.40 & 12.48 & \\
\hline \multicolumn{8}{|c|}{ LSD $_{0.05}:$ T: 0.56} \\
\hline \multicolumn{8}{|c|}{ Alkaline phosphatase activity $(\mu \mathrm{g} / \mathrm{ml})$} \\
\hline Un-inoculated & 0.92 & 0.93 & 0.94 & 0.91 & 0.90 & 0.90 & 0.91 \\
\hline A. niger & 18.80 & 38.60 & 67.13 & 45.86 & 42.86 & 38.86 & 36.18 \\
\hline A. flavus & 14.33 & 39.36 & 53.13 & 43.70 & 35.13 & 24.13 & 34.96 \\
\hline Mean & 11.35 & 26.29 & 40.40 & 30.15 & 26.29 & 21.29 & \\
\hline \multicolumn{8}{|c|}{ LSD $_{0.05}: T: 1.43$} \\
\hline
\end{tabular}

Calculated means is for triplicate measurements $\pm S D$

Notes: T: treatment ; F: fungi and TF : treatment * fungi 


\section{Effect of different temperatures on phosphate solubilization}

The maximum phosphate solubilization occurred at $30^{\circ} \mathrm{C}$ by A. niger and A. flavus (58.53 and $48.50 \mu \mathrm{g} / \mathrm{ml})$ compared to un-inoculated ones $(10.42$ $\mu \mathrm{g} / \mathrm{ml})$.A decrease in $\mathrm{P}$ solubilization occurred at temperatures above or below $30^{\circ} \mathrm{C}$. It was noticed that both $A$. niger and A. flavus were able to grow at temperature higher than $40^{\circ} \mathrm{C}$ but produce lower available P. Maximum phosphate solubilization by A. niger and A. flavus (58.53 and $48.50 \mu \mathrm{g} / \mathrm{ml}$ ), respectively were observed at $30^{\circ} \mathrm{C}$ followed by $35^{\circ} \mathrm{C}$ (48.16 and $44.63 \mu \mathrm{g} / \mathrm{ml}), 25^{\circ} \mathrm{C}(46.26$ and $35.86 \mu \mathrm{g} /$ $\mathrm{ml}), 40^{\circ} \mathrm{C}(39.23$ and $40.80 \mu \mathrm{g} / \mathrm{ml}), 20^{\circ} \mathrm{C}(34.16$ and $28.90 \mu \mathrm{g} / \mathrm{ml})$ and $45^{\circ} \mathrm{C}(32.26$ and $31.66 \mu \mathrm{g} / \mathrm{ml})$, respectively as compared to un-inoculated treatments $(8.20,8.52,10.42,10.12,9.32,9.02$ at $20,25,30$, 35,40 and temperature $45^{\circ} \mathrm{C}$, respectively (Table 6).

Table (6) : Effect of different temperatures on phosphate solubilization $(\mu \mathrm{g} / \mathrm{ml})$ produced by $\mathrm{A}$. niger and A. flavus.

\begin{tabular}{|c|c|c|c|c|c|c|c|}
\hline \multicolumn{8}{|c|}{ Phosphate solubilization $(\mu \mathrm{g} / \mathrm{ml})$} \\
\hline \multirow[b]{2}{*}{ Fungal sp. } & \multicolumn{6}{|c|}{ Temperatures $\left({ }^{\circ} \mathrm{C}\right.$ ) } & \multirow{2}{*}{ Mean } \\
\hline & 20 & 25 & 30 & 35 & 40 & 45 & \\
\hline Un-inoculated & 8.20 & 8.52 & 10.42 & 10.12 & 9.32 & 9.02 & 9.26 \\
\hline A. niger & 34.16 & 46.26 & 58.53 & 48.16 & 39.23 & 32.26 & 43.10 \\
\hline A.flavus & 28.90 & 35.86 & 48.50 & 44.63 & 40.80 & 31.66 & 38.39 \\
\hline Mean & 23.75 & 30.22 & 39.15 & 34.30 & 29.78 & 24.31 & \\
\hline \multicolumn{8}{|c|}{ LSD } \\
\hline
\end{tabular}

Calculated means is for triplicate measurements $\pm S D$

Notes: T: treatment ; F: fungi and TF : treatment * fungi

\section{Effect of different temperatures on phosphatase} activity.

In general, the maximum production of acid and alkaline phosphatase activities was assayed at $30^{\circ} \mathrm{C}$ Table (7). Then a decrease occurred at temperatures either above or below $30^{\circ} \mathrm{C}$. Maximum productions of acid phosphatase enzyme by $A$. niger and $A$. flavus $(41.23$ and $39.80 \mu \mathrm{g} / \mathrm{ml})$, respectively were ob- served at $30^{\circ} \mathrm{C}$ followed by $35^{\circ} \mathrm{C}(22.0$ and 31.63 $\mu \mathrm{g} / \mathrm{ml})$, respectively as compared to un-inoculated treatments $(0.74 \mu \mathrm{g} / \mathrm{ml})$. While the maximum productions of alkaline phosphatase enzyme by $A$. niger and A. flavus (55.56 and $46.83 \mu \mathrm{g} / \mathrm{ml}$ ), respectively were obtained at $30^{\circ} \mathrm{C}$ followed by $35^{\circ} \mathrm{C}(38.50$ and $37.96 \mu \mathrm{g} / \mathrm{ml})$, respectively as compared to un-inoculated treatments $(0.74 \mu \mathrm{g} / \mathrm{ml})$.

Table (7) : Effect of different temperatures on acid and alkaline phosphatase activity $(\mu \mathrm{g} / \mathrm{ml})$ released by $\mathrm{A}$. niger and A. flavus.

\begin{tabular}{|c|c|c|c|c|c|c|c|}
\hline \multicolumn{8}{|c|}{ Acid phosphatase activity $(\mu \mathrm{g} / \mathrm{ml})$} \\
\hline \multirow{2}{*}{ Fungal sp. } & \multicolumn{6}{|c|}{ Temperatures ( ${ }^{\circ} \mathrm{C}$ ) } & \multirow{2}{*}{ Mean } \\
\hline & 20 & 25 & 30 & 35 & 40 & 45 & \\
\hline Un-inoculated & 0.73 & 0.74 & 0.74 & 0.72 & 0.70 & 0.70 & 0.72 \\
\hline A. niger & 15.00 & 22.30 & 41.23 & 22.00 & 19.06 & 15.50 & 22.51 \\
\hline A. flavus & 11.13 & 24.70 & 39.80 & 31.63 & 26.30 & 21.80 & 25.89 \\
\hline Mean & 8.95 & 15.91 & 27.25 & 18.11 & 15.35 & 12.66 & \\
\hline \multicolumn{8}{|c|}{ LSD ${ }_{0.05}:$ T: 0.73} \\
\hline \multicolumn{8}{|c|}{ Alkaline phosphatase activity $(\mu \mathrm{g} / \mathrm{ml})$} \\
\hline Un-inoculated & 0.73 & 0.74 & 0.75 & 0.72 & 0.72 & 0.71 & 0.72 \\
\hline A. niger & 19.73 & 27.60 & 55.56 & 38.50 & 24.16 & 17.03 & 30.43 \\
\hline A.flavus & 18.26 & 34.80 & 46.83 & 37.96 & 32.50 & 30.03 & 33.39 \\
\hline Mean & 12.90 & 21.04 & 34.38 & 25.72 & 19.12 & 15.92 & \\
\hline \multicolumn{8}{|c|}{ LSD $_{0.5}: T: 1.30$} \\
\hline
\end{tabular}

Calculated means is for triplicate measurements $\pm S D$

Notes: T: treatment ; F: fungi and TF : treatment * fungi 


\section{Effect of pH on P solubilization}

Maximum phosphate solubilization by $A$. niger and A. flavus (92.33 and $92.66 \mu \mathrm{g} / \mathrm{ml}$ ) were observed at $\mathrm{pH} 7$ followed by $\mathrm{pH} 6(91.33$ and $80.56 \mu \mathrm{g} / \mathrm{ml})$ as compared to corresponding un-inoculated treatments (Table 8).

Table (8) : Effect of different pH on phosphate solubilization $(\mu \mathrm{g} / \mathrm{ml})$ induced by A. niger and A. flavus.

\begin{tabular}{|c|c|c|c|c|c|c|c|}
\hline \multicolumn{7}{|c|}{ Phosphate solubilization ( $\boldsymbol{\mu g} / \mathbf{m l})$} \\
\multirow{2}{*}{ fungal sp. } & $\mathbf{6}$ & \multirow{2}{*}{ Mean } \\
\cline { 2 - 8 } & $\mathbf{4}$ & $\mathbf{5}$ & $\mathbf{6}$ & $\mathbf{7}$ & $\mathbf{8}$ & $\mathbf{9}$ & \\
\hline Un-inoculated & 9.96 & 10.33 & 10.45 & 11.48 & 9.83 & 8.79 & $\mathbf{1 0 . 1 4}$ \\
\hline A. niger & 81.36 & 83.10 & 91.33 & 92.33 & 79.20 & 65.50 & $\mathbf{8 2 . 1 3}$ \\
\hline A. flavus & 71.06 & 71.80 & 80.56 & 92.66 & 66.76 & 50.43 & $\mathbf{7 2 . 2 1}$ \\
\hline Mean & $\mathbf{5 4 . 1 3 1}$ & $\mathbf{5 5 . 0 7 8}$ & $\mathbf{6 0 . 7 8 6}$ & $\mathbf{6 5 . 4 9 3}$ & $\mathbf{5 1 . 9 3 3}$ & $\mathbf{4 1 . 5 7 6}$ & \\
\hline \multicolumn{7}{|c|}{ T: $\mathbf{0 . 7 5} ; \mathbf{0 . 5 3 ;}$} & TF:1.30 \\
\hline
\end{tabular}

Calculated means is for triplicate measurements $\pm S D$

Notes: T: treatment ; F: fungi and TF : treatment * fungi

\section{Effect of $\mathrm{pH}$ on phosphatase activity.}

Maximum acid phosphatase activity by $A$. niger and A. flavus was detected at pH 6 (83.20 and 69.16 $\mu \mathrm{g} / \mathrm{ml})$. A decline in acid P-ase occurred from $\mathrm{pH} 7$ to $\mathrm{pH}$ 9, while the maximum production of alkaline P-ase activity accounted for $A$. niger and A. flavus (90.03 and $70.13 \mu \mathrm{g} / \mathrm{ml}$ ) was at $\mathrm{pH} 8$ compared to control treatment $(0.8 \mu \mathrm{g} / \mathrm{ml})$. A decline in phosphatase occurred at $\mathrm{pH} 6$ to $\mathrm{pH} 4$ (Table 9).

Table (9) : Effect of different $\mathrm{pH}$ on acid and alkaline phosphatase activity $(\mu \mathrm{g} / \mathrm{ml})$ produced by A. niger and A. flavus.

\begin{tabular}{|c|c|c|c|c|c|c|c|}
\hline \multicolumn{8}{|c|}{ Acid phosphatase activity $(\mu \mathrm{g} / \mathrm{ml})$} \\
\hline \multirow{2}{*}{ Fungal sp. } & \multicolumn{6}{|c|}{ pH } & \multirow{2}{*}{ Mean } \\
\hline & 4 & 5 & 6 & 7 & 8 & 9 & \\
\hline Un-inoculated & 0.84 & 0.85 & 0.86 & 0.83 & 0.82 & 0.80 & 0.83 \\
\hline A. niger & 46.10 & 57.23 & 83.20 & 77.33 & 74.46 & 58.36 & 66.11 \\
\hline A. flavus & 39.26 & 42.93 & 69.16 & 64.53 & 51.30 & 51.43 & 53.10 \\
\hline Mean & 28.73 & 33.67 & 51.07 & 47.56 & 42.19 & 36.86 & \\
\hline \multicolumn{8}{|c|}{ LSD $_{0.05}:$} \\
\hline \multicolumn{8}{|c|}{ Alkaline phosphatase activity $(\mu \mathrm{g} / \mathrm{ml})$} \\
\hline Un-inoculated & 0.84 & 0.86 & 0.87 & 0.88 & 0.84 & 0.83 & 0.85 \\
\hline A. niger & 56.33 & 69.36 & 82.80 & 88.86 & 90.03 & 81.50 & 78.15 \\
\hline A. flavus & 51.53 & 57.36 & 58.86 & 60.16 & 70.13 & 74.26 & 62.05 \\
\hline Mean & 36.23 & 42.52 & 47.51 & 49.96 & 53.66 & 52.19 & \\
\hline \multicolumn{8}{|c|}{ LSD $_{0.05}:$} \\
\hline
\end{tabular}

Calculated means is for triplicate measurements $\pm S D$

Notes: T: treatment ; F: fungi and TF : treatment * fungi

\section{DISCUSSION}

Hefnawy et al. (2014) found that out of all 20 fungi isolated from the salinity soils, only two fungi showed significant zone of P solubilization (Penicillium oxalicum and Penicillium expansum). Yasser et al. (2014) reported that Aspergillus, Penicillium 
and Trichoderma were the most important PSF genera isolated from different localities and different habitats in Beni-suef governorate, after 4 days of incubation PVK agar plate, these results are in agreement with our results. At the same time Gupta et al. (2007) found that the continuous observation of the halo zone was in increasing order up to the $7^{\text {th }}$ day. Chuang et al. (2007), Oniya et al. (2015) and Verma and Ekka (2015) also isolated P-solubilizing fungi such as $A$. niger and Penicillium spp from various rhizospheric soil samples.

El-Azounil (2008) reported that SI of $A$. niger was greater than $P$. italicum and also this kind of comparable results have been reported by many investigators (Afzal et al., 2005 and Gupta et al., 2007). Also, Iman (2008) reported that SI of the test PSF strains ( $P$. italicum and A. niger) were 2.42 and 3.15, respectively. Conversely, Mahamuni et al. (2012) reported that SI for different fungal strains isolated from sugarcane and sugar beet ranged from 1.13 to 1.59. Also, Das et al. (2013) reported that among PSM, Trichoderma asperellum was most efficient phosphate solubilizer on Pikovskaya's agar plates with $\mathrm{SI}=1.87$, followed by $T$. harzianum, $T$. viride, T. citrinoviride with a SI of 1.79, 1.68 and 1.62 respectively, while, A. niger and A. flavus showed SI value of 1.58 and 1.52 respectively and the least was noted by $P$. funiculosum with a SI value of 1.41, these results are in agreement with the present study. Achal et al. (2007) whom reported that the Aspergillus sp showed highest available phosphate when tri-calcium phosphate was used and also showed maximum acid phosphatase and alkaline phosphatase. Iqbal et al . (2016) reported that, the phosphate solubilizing index (PSI) of fives rhizobacterial isolate ranged from 2.33 to 3.17 and maximum PSI was observed by S5. S5 isolates showed lowest available phosphate than S3 and S1. However S5 showed maximum acid phosphatase acid phosphatase and alkaline phosphatase than S3 and S1. Deepa et al. (2010) found that the acid phosphatase activity of $P$. chrysogenum and $T$. viride were more, they released less amount of phosphorus which is due to the non-specific binding activity of the phosphatase. PSF play an important role in phosphate solubilization through extrusion of acid phosphatases and phytases enzymes (Aseri et al., 2009).

Pandey et al. (2008) who observed themaximum solubilization of phosphate occurring at day 15 of incubation for TCP under controlled conditions. Vyas et al. (2007) reported that a significant increase with the prolongation of incubation period from 3 to 9 days, followed by a significant decline after 12 days of incubation. Narsian and Patel (2000) reported that the maximum release of $\mathrm{P}$ from China and Udaipur RPs and Sonrai and Hirapur RPs by $A$. aculeatus after 8 and 14 days of incubation. The decrease in $\mathrm{P}$ content with the advance of incubation period could be attributed to the utilization of $\mathrm{P}$ by fungal species resulting in the fluctuating levels of $\mathrm{P}$ release (Deepa et al., 2010).

The optimum incubation temperature for maximum values of $\mathrm{P}$ solubilization and maximum production of acid and alkaline phosphatase activities by both $A$. niger and A. flavus were at $30{ }^{\circ} \mathrm{C}$. The present finding is in accordance with the study where in $30^{\circ} \mathrm{C}$ resulted in maximum phosphate solubilization by A. niger PSF4 (Bhattacharya et al., 2015). Similarly, other workers found $30^{\circ} \mathrm{C}$ to be best temperature for phosphate solubilization by $A$. niger (Saber et al., 2009). Although many researchers reported phosphate solubilization at different temperatures, most of them suggested $25^{\circ} \mathrm{C}$ to be the optimal temperature for phosphate solubilization (Sayer and Gadd, 1998). Higher or lower than optimal temperature, the content of soluble $\mathrm{P}$ decreased, the results are in similar to those of (Barroso and Nahas, 2005).

At $\mathrm{pH}$ values higher or lower than the optimal $\mathrm{pH}$, the content of soluble phosphorus decreased (Saber et al., 2009). Xiao et al. (2008) reported that there was remarkable reduction in the content of soluble $\mathrm{P}$ at higher or lower than the optimal $\mathrm{pH}$, the 
obtained result in this work are in agreement with the other studies.

\section{REFERENCES}

- Achal, V.; Savant, V.V. and Reddy, M.S. (2007): Phosphate solubilization by a wild type strain and UV-induced mutants of Aspergillus tubingensi. Soil. Biol. Biochem., 39(2): 695.

- Afzal, A.; Ashraf, M.; Asad, A.S. and Farooq, M.(2005): Effect of phosphate solubilizing microorganisms on phosphorus uptake, yield, and yield traits of wheat (Tritium aestivum) in rain fed area. Int. J. Agri. Biol., 7(2): 209.

- $\quad$ Aseri, GK.; Jain, N. and Tarafdar, J.C. (2009): Hydrolysis of organic phosphate forms by phosphatases and phytase producing fungi of arid and semiarid soils of India. Am. Eur. J. Agric. Environ. Sci., 5: 570 .

- Barroso, C.B. and Nahas, E. (2005): The status of soil phosphate fractions and the ability of fungi to dissolve hardly soluble phosphates. Appl. Soil Ecol., 29: 73.

- Bhatacharya, S.; Das, A.; Bhardwaj, S. and Rajan, S.S. (2015): Phosphate solubilizing potential of $A s$ pergillus niger MPPF- 8 isolated from Multhupettai Mangrove. J. Sci. industr. Res., 74: 503.

- Chuang, C.-C.; Kuo, Y.-L.; Chao, C.-C. and Chao, W.-L. (2007): Solubilization of inorganic phosphates and plant growth promotion by Aspergillus niger. Biol. Fert. Soils, 43(5): 575.

- Coutinho, F.P.; Felix, W.P. and Yano-Melo, M. (2012): Solubilization of phosphates in vitro by $A s$ pergillus sp .and Penicillium sp. Ecol. Eng., 42: 85.

- $\quad$ Das, A.; Dutta, B.K. and Barooah, A.K. (2013): In vitro Solubilization of Inorganic Phosphate by Phosphate Solubilizing Fungi Isolated from Tea Agroecosystem Soil of Barak Valley, Southern Assam. Int. J. Microbiol. Res., 4(3): 336.

- Deepa, V.; Aadarsh, P.; Balakrishna, M.P. and Sridhar, R. (2010): Efficient phosphate solubiliza- tion by fungal strains isolated from rice-rhizosphere soils for the phosphorus release. Res. J. Agric. Biol. Sci., 6: 487.

- Dox, A.W. (1910): The Extracellular Enzymes of Penicillium and Aspergillus with special references to these of P. amenberte. U.S. Dept. Agri. Bur. Anim. Ind. Bull., 170 Environ. Int., 26: 417.

- Edi-Premono, M. (1996): Effect of phosphate-solubilizing Pseudomonas Putida on the growth of maize rhizosphere. Indo. J. Crop. Sci., 11: 13.

- El-Azouni, I.M. (2008): Effect of phosphate solubilizing fungi on growth and nutrient uptake of soybean (Glycine max I.) plants. J. App. Sci. Res.,4: 592.

- Gupta, N.; Sabat, J. and Parida, R. (2007): Solubilization of tri-calcium phosphate and rock phosphate by microbes isolated from chromite, iron and manganese mines. Acta. Bot. Croat., 66: 197.

- Hefnawy, M.A.; Maisa, M. and Shalaby, G.M. (2014): Influence of salinity on phosphate solubilization by fungi. Middle East J. Appl. Sci., 4(4):1080.

- Hyland, C.; Ketterings, Q.; Dewing, D.; Stockin, K.; Czymmek, K. and Albrecht, G. (2005): Phosphorus basics- The phosphorus cycle. Agro. Fact. Sheet Series., 12: 1.

- Iman, M. (2008): Effect of phosphate solubilizing fungi on growth and nutrient uptake of soyabean (Glycine $\max$ L.) plants. J. Appl. Sci. Res., 4: 592.

- Iqbal, S.; Khan, M.Y.; Asghar, H.N. and Akhtar, M.J. (2016):Combined use of phosphate solubilizing bacteria and poultry manure to enhance the growth and yield of mung bean in calcareous soil. Soil Environ., 35(2): 146.

- Mahamuni, S.V.; Wani, P.V. and Patil, A.S. (2012): Isolation of phosphate solubilizing fungi from rhizosphere of sugarcane \& sugar beet using TCP \& RP solubilization. Asian J. Bio. Pharma. Sci., 2: 244.

- Maougal, R.T.; Brauman, A.; Plassard, C.; Abadie, J.; Djekoun, A. and Drevon, J.J. (2014): Bacterial capacities to mineralize phytate increase in the rhizosphere of nodulated common bean (Phaseolus 
vulgaris L.) under P deficiency. J. Soil Biol., 62: 8.

- Narsian, V. and Patel, H.H. (2000): Aspergillus aculeatus as a rock phosphate solubilizer. Soil Biol. Biochem., 32: 559.

- Olsen, S.R.; Cole, C.V.; Watanabe, F.S. and Dean, L.A. (1954): Estimation of available phosphorus in soils by extraction with sodium bio-carbonate. US Department of Agriculture circular No. 939.USDA, Washing ton. D.C.

- Onyia, C.E.; Anyawu, C.U. and Ikegbunam, M.N. (2015): Ability of fungi, isolated from nsukka peppers and garden-egg plant rhizospheres, to solubilize phosphate and tolerate cadmium. Adv. Microbiol., 5(7): 500 .

- Pandey, A.; Das, N.; Kumar, B.; Rinu, K. and Trivedi, P. (2008): Phosphate solubilization by Penicillium spp. isolated from soil samples of Indian Himalayan region. World J. Microbiol. Biotechnol., 24(1): 97.

- Pikovskaya, R.I. (1948): Mobilization of phosphorus in soil connection with the vital activity of some microbial species . Microbiol., 17:362.

- Pitt, J.I. (1979): Geosmithia gen. nov for Penicillium lavendulum and related species. Can. J .Bot., 57: 2021.

- Pitt, J.I. and Hocking, A.D. (1985): Interfaces among genera related to Aspergillus and Penicillium. Mycologia, 77(5): 810.

- Pitt, J.I. and Hocking, A.D. (1997): Fungi and food spoilage. $2^{\text {nd }}$ Edition, Blackie Academic and Professional, London.

- Podile, A.R. and Kishore, G.K. (2006): Plant Growth-Promoting Rhizobacteria. In: Gnana -manickam (ed.). Plant Associ. Bact., 195.

- Reghab, H.M.A.; Attia, K.K.; Abd El-Galil, A. and Bakr, A.A. (2010): Phosphorus status in soils of great groups in Qena governorate. J. Environ. Stud. 5: 21.

- Richardson, A.E. and Simpson, R.J. (2011): Soil microorganisms mediating phosphorus availability. Plant Physiol., 156: 989.
- Rodriguez, H.; Fraga, R.; Gonzalez, T. and Bashan, Y. (2006): Genetics of phosphate solubilization and its potential applications for improving plant growth-promoting bacteria. Plant Soil, 287: 15.

- Saber, W.I.A.; Ghanem, K.M. and EI-Hersh, M.S. (2009): Rock phosphate solubilization by two isolates of Aspergillus niger and Penicillium sp. and their promotion to mung bean plants. Res. J. Micrrobiol., 4: 235.

- Sagervanshi, A.; Kumari, P.; Nagee, A. and Kumar, A. (2012): Isolation and characterization of phosphate solublizing bacteria from sand and agriculture soil. Int. J. Sci. Res., 23: 256.

- Sayer, J.A. and Gadd, G.M. (1998): Solubilization and precipitation of metals by fungi. Mineral. Soc. Bull., 120: 3 .

- Snedcor, G.W. and Cochran, W.G. (1980): Statistical Methods, $7^{\text {th }}$ ed. Iowa state Univ. press Iowa, USA.

- Tabatabai, M.A. and Bremner, J.M. (1969): Use of $p$-nitrophenyl phosphate for assay of soil phosphatase activity. Soil. Bio. Biochem., 1: 301.

- Velazquez, E. and Rodriguez-Barrueco, C. (2007): First international meeting on microbial phosphate solubilization (Developments in Plant and Soil Scince vol 102). Springer, The Netherlands.

- Verma, A. and Ekka, A. (2015): Assessment of phosphate solubilizing potential of fungal isolates from soils of three blocks of Raipur, Chhattisgarh, India. J. Ravishankar University Part B: Sci., 28(2): 44.

- Vyas, P.; Rahi, P.; Chauhan, A. and Gulati, A. (2007): Phosphate solubilization potential and stress tolerance of Eupenicillium parvum from tea soil. Mycolog. Res., 111: 931.

- Xiao, C.Q.; Zhang, H.X.; Fang, Y.J. and Chi, R. (2013): Evaluation of rock phosphate solubilization in fermentation and soil-plant system using a stresstolerant phosphate-solubilizing Aspergillus niger WHAK1. Appl. Microbiol. Biotech., 169(1): 123.

- Xiao, C.Q.; Chi, R.A.; Huang, X.H.; Zhang, W.X.; 
Qiu, G.Z. and Wang, D.Z. (2008): Optimization for rock phosphate solubilization by phosphate-solubilizing fungi isolated from phosphate mines. Ecol. Eng., 33: 187.

- Yasser, Manal M.; Ahmad, S.M.; Osama, N.M. and Siada, H.N. (2014): Solubilization of inorganic phosphate solubilizing fungi isolated from Egyptian soils. J. Biol. Earth. Sci., 4(1): B83. 


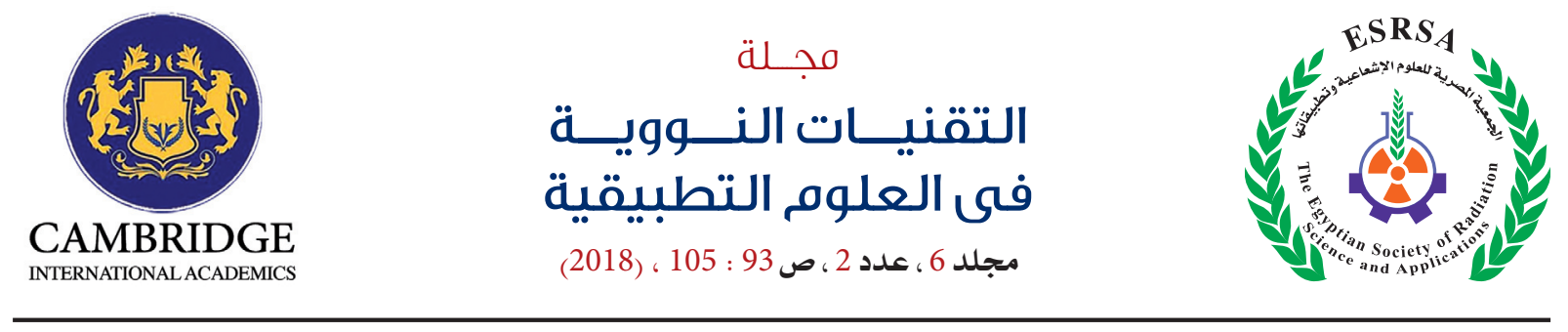

\title{
عزل وتوصيف للفطريات المذيبتت للفوسفات فى المعمل
}

\begin{abstract}
'اسماعيل ابو سريع الغندور', سعديه محمد حسانين عيسى' ، أسامت عبدالباسط عبدالعزيز' , عبير محمد موسى' ,
أجريت سلسلت من التجارب المخبريت (يِّ المعمل) للتعرف على أكثر عزلات الفطريات

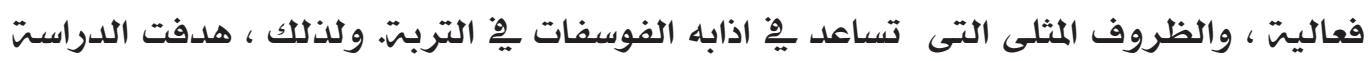

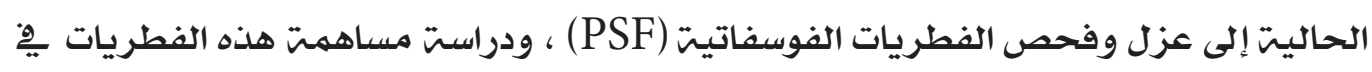

إذابت ثلاثي فوسفات الكالسيوم من خلال إفراز الفوسفاتيزالحمضى والقلوى وتحديد الظروف

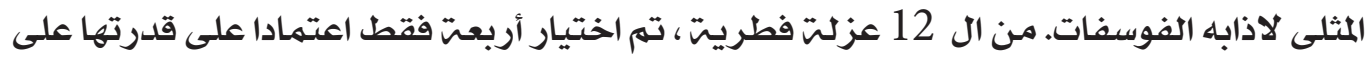

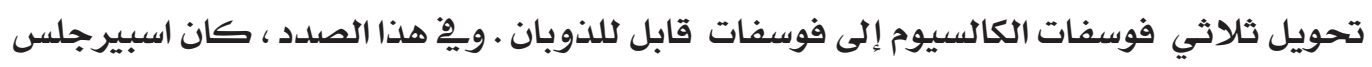
نيجر ، اسبيرجلس فلافس ، اسبيرجلس فيكوم وفيوزاريم أوكسيسبوريوم الاكثر فعاليت يِّي إنتاج منطقت الهالت حول المستعمـرات على طبق بتري.وكان اسبيرجلس نيجر الاكثر فعاليتة

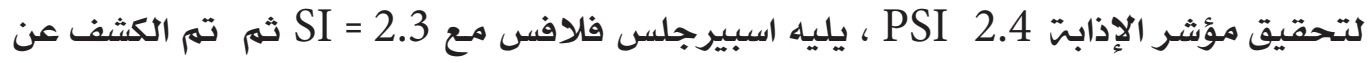

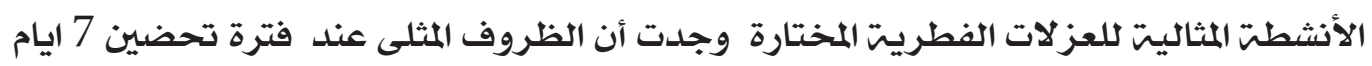
وعند درجه حراره 30 درجت مئويت لإنتاج أعلى قيم للفوسفات المذاب وافراز انزيم الفوسفاتيز الحمضي والقلوي واظهرت النتائج ايضا ان الرقم الهيدروجيني 7 اعطى اعلى قيمـه للفوسفات

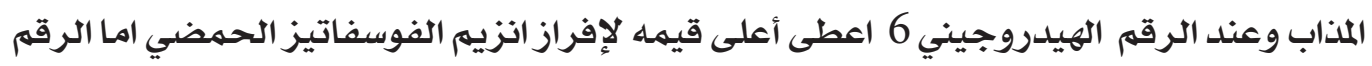
الهيدروجيني 8 فقد اعطى أعلى قيمه لإفراز انزيم الفوسفاتيز القلوي لكلا من اسبيرجلس نيجير لإسر واسبيرجلس فلافس.

الكلمات الرئيسيتّ: اذابتالفوسفات ، ثلاثى فوسفات الكالسيوم، انزيمالفوسفاتيز والفطريات المذيبتة للفوسفات. 
